\title{
OBITUARY
}

\section{THOMAS S. GRAHAM}

Dr Graham, who was President of the Society during the session 1952-53, died at his home in Glasgow on 26th January 1974. He was born on 25th July 1905 at Stepps, where his father was station-master, and was one of three brothers all of whom had notable careers at Glasgow University. A pupil of Allan Glen's School, he entered the University in 1922 and graduated Master of Arts with First Class Honours in Mathematics and Natural Philosophy in 1926. As the most distinguished graduate in the Faculty of Arts in his year, he was awarded the Logan Medal and Prize.

It was his wish to prosecute his studies further at Cambridge; but in those days the only scholarship that could have enabled him to do this was the Bryce Fellowship, which had been held since 1924 by his future colleague and friend, Robert Gillespie. Graham therefore marked time by registering as a research student in the Department of Natural Philosophy under the late Professor E. Taylor Jones, and supported himself financially by a Ferguson Scholarship in Mathematics, which he won in 1926 in competition with candidates from the four Scottish universities.

In 1928 the Bryce Fellowship became available and was awarded to him after he had sat the required examination. What student nowadays would care to take an examination on his Honours course two years after graduating? He went up to Gonville and Caius College, Cambridge, as a research student under the supervision of M. H. A. Newman. Newman had a high regard for Graham's abilities and it was through him that Graham was enabled to spend two years as a Graduate Student in Princeton from 1930 to 1932. These were extremely important and stimulating years for him. His immediate supervisor was L. P. Eisenhart, but it was the distinguished geometer Oswald Veblen who influenced him most and, at a less advanced level, he benefited from contacts with other rising young mathematicians such as the late J. H. C. Whitehead.

Graham was a perfectionist, always seeking for the best and most illuminating way of expressing his work. This quality prevented him from submitting for publication the results of his research (for which he received his Ph.D. from Cambridge in 1932) until it was too late to do so as others had got in before him. However, some of his work may be seen in Eisenhart's book Continuous Groups of Transformations (Princeton, 1933), where his achievements and assistance are acknowledged.

On his return to Glasgow in 1932 Graham was appointed an Assistant by the late Professor MacRobert and became a Lecturer in 1935. He entered fully into the teaching work of the Department, giving careful attention to the preparation of lectures, but retaining through wide reading his interest in abstract and linear algebra. Before the Second World War, Mathematics was studied as an Honours subject almost entirely in combination with Natural Philosophy, and there was therefore a natural tendency to devote more time to the different aspects of mathematical analysis than to algebra. Although Graham was as capable and willing as any member of staff to lecture on subjects such as differential equations, he used his influence to ensure that algebra was given its proper place in the curriculum, 
and it was due to his efforts that the distinguished German algebraist, Hans Zassenhaus spent the year 1948-49 in Glasgow and became his close friend.

Graham had an excellent and ready command of English and Scots, and was an able and amusing speaker at students' final year dinners and on similar occasions. As a member of the Faculty of Science and of Senate his contributions were always well thought out and sensible. He was one of the original editors of the Glasgow Mathematical Journal, which was founded by Professor MacRobert in 1952; the detailed editorial work was his chief responsibility and made full use of his meticulous qualities. He continued this work after his retirement in 1970 and this compensated in a small measure for his regret at giving up his work of teaching and advising students, which he had so much enjoyed and carried out so well and sympathetically.

Tommy Graham was a cheerful man, a loyal colleague and an able mathematician. He is survived by his widow, a daughter and two sons.

R. A. RANKIN 